OPEN ACCESS

Edited by:

Avelino Alvarez-Ordóñez, Teagasc Food Research Centre,

Ireland

Reviewed by:

Diego Garcia-Gonzalo,

University of Zaragoza, Spain

Karen LeGrand,

University of California, Davis, USA

*Correspondence.

Riikka Keto-Timonen

riikka.keto-timonen@helsinki.fi

Specialty section:

This article was submitted to

Food Microbiology,

a section of the journal

Frontiers in Microbiology

Received: 12 May 2016

Accepted: 11 July 2016

Published: 22 July 2016

Citation:

Keto-Timonen R, Hietala $N$,

Palonen E, Hakakorpi $A$,

Lindström M and Korkeala H (2016)

Cold Shock Proteins: A Minireview with Special Emphasis on Csp-family

of Enteropathogenic Yersinia.

Front. Microbiol. 7:1151.

doi: 10.3389/fmicb.2016.01151

\section{Cold Shock Proteins: A Minireview with Special Emphasis on Csp-family of Enteropathogenic Yersinia}

\author{
Riikka Keto-Timonen*, Nina Hietala, Eveliina Palonen, Anna Hakakorpi, Miia Lindström \\ and Hannu Korkeala
}

Department of Food Hygiene and Environmental Health, Faculty of Veterinary Medicine, University of Helsinki, Helsinki, Finland

Bacteria have evolved a number of mechanisms for coping with stress and adapting to changing environmental conditions. Many bacteria produce small cold shock proteins (Csp) as a response to rapid temperature downshift (cold shock). During cold shock, the cell membrane fluidity and enzyme activity decrease, and the efficiency of transcription and translation is reduced due to stabilization of nucleic acid secondary structures. Moreover, protein folding is inefficient and ribosome function is hampered. Csps are thought to counteract these harmful effects by serving as nucleic acid chaperons that may prevent the formation of secondary structures in mRNA at low temperature and thus facilitate the initiation of translation. However, some Csps are non-cold inducible and they are reported to be involved in various cellular processes to promote normal growth and stress adaptation responses. Csps have been shown to contribute to osmotic, oxidative, starvation, $\mathrm{pH}$ and ethanol stress tolerance as well as to host cell invasion. Therefore, Csps seem to have a wider role in stress tolerance of bacteria than previously assumed. Yersinia enterocolitica and Yersinia pseudotuberculosis are enteropathogens that can spread through foodstuffs and cause an enteric infection called yersiniosis. Enteropathogenic Yersinia are psychrotrophs that are able to grow at temperatures close to $0^{\circ} \mathrm{C}$ and thus they set great challenges for the modern food industry. To be able to efficiently control psychrotrophic Yersinia during food production and storage, it is essential to understand the functions and roles of Csps in stress response of enteropathogenic Yersinia.

\section{Keywords: adaptation, Csp, cold stress, stress response, stress tolerance, Yersinia enterocolitica, Yersinia} pseudotuberculosis

\section{INTRODUCTION}

Bacteria encounter changing environmental conditions during food production and storage and they have evolved a number of mechanisms for coping with stress and adapting to changing environments. In modern food production refrigeration is one of the key elements in maintaining food safety. At cell level temperature downshift decreases the fluidity of cell membranes, which affects active transport and protein secretion (Phadtare and Severinov, 2010). In addition, the efficiency of transcription and translation is reduced due to stabilization of the secondary structures of DNA and RNA, protein folding is inefficient, and ribosomes need to be adapted to cold before they can function properly (Phadtare, 2004). The aim of cold shock response is to help bacterial cells to overcome these changes (Phadtare and Severinov, 2010). 
Bacteria respond to a rapid temperature drop (cold shock) by a transient induction of cold induced proteins (Cips) (Graumann and Marahiel, 1996; Phadtare, 2004) and the production of Cips increases with the severity of the cold shock (Hébraud and Potier, 1999). In Escherichia coli numerous Cips have been identified so far including, e.g., cold shock protein (Csp) family (Yamanaka et al., 1998), RNA helicase csdA (Charollais et al., 2004), exoribonucleases PNPase and RNaseR (Phadtare, 2012), initiation factors $2 \alpha$ and $2 \beta$, NusA and RecA (Jones et al,, 1987). This minireview focuses on a subgroup of Cips, the small homologous Csps that are classified together in the Cspfamily.

Cold shock proteins counteract some harmful effects of temperature downshift and thus help the cells to adapt (Phadtare, 2004). After the immediate cold shock response, the synthesis of Csps declines and synthesis of other proteins increases. This enables the cells to grow at low temperature, although at a slower rate (Ermolenko and Makhatadze, 2002). Csps are known to be important during cold shock response, however, recent studies have shown that Csps might have a wider role in stress tolerance of bacteria (Schmid et al., 2009; Duval et al., 2010; Loepfe et al., 2010; Michaux et al., 2012; Schärer et al., 2013; Wang et al., 2014; Derman et al., 2015).

Yersinia enterocolitica and Yersinia pseudotuberculosis are enteropathogens that can cause a foodborne enteric infection called yersiniosis. In 2013, yersiniosis was the third most frequently reported zoonosis in the European Union (EFSA and ECDC, 2015). Food products containing pork are considered to be the main vehicles of $Y$. enterocolitica infection (FredrikssonAhomaa et al., 2006), whereas large Y. pseudotuberculosis outbreaks have been linked to contaminated vegetables (Nuorti et al., 2004; Jalava et al., 2006), drinking water (Fukushima et al., 1988), and raw milk (Pärn et al., 2015).

Yersinia enterocolitica and $Y$. pseudotuberculosis are psychrotrophic bacteria that can grow even at temperatures close to $0^{\circ} \mathrm{C}$ (Fredriksson-Ahomaa et al., 2010). The control of Yersinia in the modern food chain involving refrigeration as the sole means to increase the shelf life of food products is thus challenging. To be able to efficiently control enteropathogenic Yersinia in refrigerated foods, a thorough knowledge of their cellular adaptation mechanisms to changing environments during food production and storage is needed. This minireview summarizes the current understanding of the functions of Csp-family proteins and highlights what is currently known about their role in stress response of enteropathogenic Yersinia.

\section{COLD SHOCK PROTEINS}

Cold shock proteins are small nucleic acid-binding proteins ranging from 65 to 75 amino acids in length (Graumann and Marahiel, 1996; Czapski and Trun, 2014) and they have been found in psychrophilic, mesophilic, thermophilic and even hyperthermophilic bacteria (Phadtare, 2004; Jin et al., 2014). CspA was first described in E. coli (Goldstein et al., 1990). Later it was found that E. coli CspA family consists of nine homologous proteins named CspA through CspI that share a 46-91\% amino acid sequence similarity (Yamanaka et al., 1998). Similar naming has been used in other bacteria as well, but genes with identical names do not necessarily share identical structure or function in different bacteria.

Structurally Csps are highly conserved, however, their thermostability varies (Lee et al., 2013; Jin et al., 2014). CspA of the psychrotrophic Listeria monocytogenes has a melting temperature of $40^{\circ} \mathrm{C}$ (Lee et al., 2013), whereas Csp of thermophilic Thermus aquaticus has a more rigid structure and a melting temperature as high as $76^{\circ} \mathrm{C}$, suggesting that psychrophilic Csps need higher structural flexibility to accommodate nucleic acids upon cold shock (Jin et al., 2014). At $37^{\circ} \mathrm{C}$, the $\operatorname{csp} A$ mRNA of $E$. coli is very unstable, its half-life being only $12 \mathrm{~s}$, but after cold shock its stability increases producing a half-life of more than $20 \mathrm{~min}$ (Mitta et al., 1997). Transient cspA mRNA stabilization due to low temperature is probably an important factor in the induction of CspA during cold shock (Phadtare and Severinov, 2005).

\section{FUNCTION OF COLD SHOCK PROTEINS DURING COLD SHOCK}

Csps have a highly conserved nucleic acid binding domain, called the cold shock domain (CSD) (Graumann and Marahiel, 1996). CSD contains two nucleic acid binding motifs, ribonucleoprotein 1 and 2 (Lee et al., 2013) that facilitate binding to target RNA and DNA (Chaikam and Karlson, 2010). Jiang et al. (1997) demonstrated that CspA of E. coli binds weakly and with low sequence specificity to ssRNA. Csps function as RNA chaperones by destabilizing secondary structures in target RNA at low temperature so that the single-stranded state of target RNA is maintained. This enables efficient transcription and translation (Jiang et al., 1997; Phadtare, 2004). The weak and low sequence specific binding of RNA is important for the chaperone function of CspA and its homologues. Otherwise the movement of ribosomes on target mRNA would be hindered (Yamanaka, 1999). Due to the chaperone function, Csps can also act as transcription antiterminators by preventing formation of hairpin structures, which can act as transcriptional termination or pause sites in target RNA at low temperatures (Bae et al., 2000; Phadtare et al., 2002).

The cspA mRNA of $E$. coli can sense temperature changes and adapt to these changes by adopting different functional structures (Giuliodori et al., 2010). Giuliodori et al. (2010) showed that at low temperature the $\operatorname{csp} A$ mRNA derived from E. coli undergoes a temperature dependent structural change and as a result the $\operatorname{csp} A$ mRNA is translated more efficiently and is less prone to degradation than the $\operatorname{csp} A$ mRNA structure at $37^{\circ} \mathrm{C}$. Similarly, Mega et al. (2010) discovered that cold-induced ttcsp2 of thermophilic Thermus thermophilus acts as a thermosensor by adopting a more stable secondary structure due to a temperature drop.

Only CspA, B, CspE, G and CspI of E. coli are induced by cold shock (Etchegaray et al., 1996; Nakashima et al., 1996; Wang et al., 1999; Uppal et al., 2008) (Table 1). Xia et al. (2001) discovered that in $E$. coli four out of nine $\operatorname{csp}$ genes $(\operatorname{csp} A, \operatorname{csp} B$, 


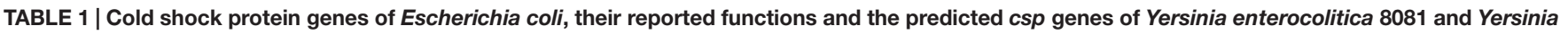
pseudotuberculosis IP32953 that share the highest amino acid sequence similarity (in percentage) ${ }^{\mathrm{a}}$ with csp genes of Escherichia coli K-12 W3110.

\begin{tabular}{|c|c|c|c|c|c|c|}
\hline \multirow[b]{2}{*}{$\begin{array}{l}\text { csp genes } \\
\text { of } E \text {. coli }\end{array}$} & \multirow[b]{2}{*}{ Reported function } & \multirow[b]{2}{*}{ Reference(s) } & \multicolumn{2}{|c|}{$\begin{array}{c}\text { csp gene with highest similarity in } \\
\text { Y. enterocolitica } 8081\end{array}$} & \multicolumn{2}{|c|}{$\begin{array}{l}\text { csp gene with highest similarity in } \\
\text { Y. pseudotuberculosis IP32953 }\end{array}$} \\
\hline & & & $\begin{array}{c}\text { Gene } \\
\text { name(s) }\end{array}$ & $\begin{array}{c}\text { Amino acid sequence } \\
\text { similarity }(\%)\end{array}$ & $\begin{array}{c}\text { Gene } \\
\text { name(s) }\end{array}$ & $\begin{array}{l}\text { Amino acid sequence } \\
\text { similarity (\%) }\end{array}$ \\
\hline $\operatorname{csp} A$ & $\begin{array}{l}\text { Induced by cold } \\
\text { Major cold shock protein of } \\
\text { E. coli }\end{array}$ & $\begin{array}{l}\text { Jones et al., 1987; } \\
\text { Goldstein et al., } 1990\end{array}$ & YE3823 & 78.57 & YРТВ3587 & 74.29 \\
\hline $\operatorname{csp} B$ & Induced by cold & Etchegaray et al., 1996 & YE3823 & 80.00 & $\begin{array}{l}\text { YРTB3585, } \\
\text { YРTB3586 }\end{array}$ & 77.14 \\
\hline $\operatorname{cspC}$ & $\begin{array}{l}\text { Involved in regulation of } \\
\text { expression of stress response } \\
\text { proteins RpoS and UspA } \\
\text { Involved in regulation of } \\
\text { growth }\end{array}$ & $\begin{array}{l}\text { Phadtare and Inouye, } \\
\text { 2001; Rath and Jawali, } \\
\text { 2006; Cohen-Or et al., } \\
\text { 2010; Shenhar et al., } \\
2012\end{array}$ & $\begin{array}{l}\text { YE2590, } \\
\text { YE3012 }\end{array}$ & 81.16 & YРТВ1624 & 98.55 \\
\hline $\operatorname{csp} D$ & $\begin{array}{l}\text { Induced by stationary phase } \\
\text { growth and nutrient starvation } \\
\text { Involved in persister cell } \\
\text { formation and biofilm } \\
\text { development } \\
\text { Inhibits DNA replication } \\
\text { Overproduction of CspD is } \\
\text { toxic for the cell }\end{array}$ & $\begin{array}{l}\text { Yamanaka and Inouye, } \\
\text { 1997; Xia et al., 2001; } \\
\text { Yamanaka et al., 2001; } \\
\text { Kim and Wood, 2010; } \\
\text { Kim et al., } 2010\end{array}$ & YE1516 & 83.78 & YРTВ1392 & 83.78 \\
\hline $\operatorname{csp} E$ & $\begin{array}{l}\text { Induced by cold } \\
\text { Involved in regulation of } \\
\text { expression of stress response } \\
\text { proteins RpoS and UspA } \\
\text { CspE constitutively produced } \\
\text { at } 37^{\circ} \mathrm{C} \text {, increase in } \\
\text { production during lag phase }\end{array}$ & $\begin{array}{l}\text { Bae et al., 1999; } \\
\text { Phadtare and Inouye, } \\
\text { 2001; Shenhar et al., } \\
\text { 2012; Czapski and } \\
\text { Trun, } 2014\end{array}$ & YE3012 & 91.30 & YPTB1088 & 94.20 \\
\hline $\operatorname{csp} F$ & $\begin{array}{l}\text { Expressed at very low level, } \\
\text { no protein has been detected } \\
\text { from the gene. Function } \\
\text { unknown }\end{array}$ & Czapski and Trun, 2014 & $\begin{array}{l}\text { YE3821, } \\
\text { YE3822, } \\
\text { YE3823 }\end{array}$ & 48.57 & $\begin{array}{l}\text { YРТВ3585, } \\
\text { YРТВ3586, } \\
\text { YРТВ3587 }\end{array}$ & 48.57 \\
\hline $\operatorname{csp} G$ & Induced by cold & Nakashima et al., 1996 & YE3823 & 81.43 & $\begin{array}{l}\text { YРТВ2950, } \\
\text { YРTВ3587 }\end{array}$ & 77.14 \\
\hline $\mathrm{cspH}$ & $\begin{array}{l}\text { Expressed at very low level, } \\
\text { no protein has been detected } \\
\text { from the gene. Function } \\
\text { unknown }\end{array}$ & Czapski and Trun, 2014 & $\begin{array}{l}\text { YE3821, } \\
\text { YE3822, } \\
\text { YE3823 }\end{array}$ & 50.00 & $\begin{array}{l}\text { YРТВ3585, } \\
\text { YРТВ3586, } \\
\text { ҮРТВ3587 }\end{array}$ & 51.43 \\
\hline $\operatorname{cspl}$ & Induced by cold & Wang et al., 1999 & YE3823 & 84.29 & YРTВ3587 & 82.86 \\
\hline
\end{tabular}

aAlignments were calculated using Clustal Omega v.1.2.1. Nucleotide and amino acid sequences were derived from The Kyoto Encyclopedia of Genes and Genomes (Kanehisa et al., 2016).

$\operatorname{csp} E$, and $\operatorname{csp} G)$ had to be deleted until cold sensitive phenotype was obtained. In addition, deletion of one or two csp genes increased and prolonged the expression of the remaining cold induced $\operatorname{csp}$ genes. This indicates that the functions of the CspA family members overlap and they can compensate for each other (Xia et al., 2001). Similarly in Bacillus subtilis, the loss of one or two csp genes increased the production of remaining Csps after cold shock (Graumann et al., 1997). In E. coli, temperature fluctuation between $37^{\circ} \mathrm{C}$ and $8^{\circ} \mathrm{C}$ increased the $\operatorname{csp} A$ and $\operatorname{csp} B$ transcription during each temperature downshift whereas transcription decreased when temperature was raised (Ivancic et al., 2013). However, the CspA and CspB protein concentrations were only increased during the first temperature downshift and the relative protein levels remained constant during temperature fluctuations suggesting that the proteins are rather stable and not degraded at higher temperature (Ivancic et al., 2013). Csps may aid bacteria to survive in extremely cold polar environment. Jung et al. (2010) discovered that when the CspA of psychrophilic Psychromonas arctica isolated from Artic sea sediments was overexpressed in E. coli, the survival of cells after repeated freezing and thawing increased over 10-fold.

Mesophilic Clostridium botulinum Group I and III strains have two or three $\operatorname{csp}$ genes $(\operatorname{csp} A, \operatorname{csp} B$ and $\operatorname{csp} C)$, but of the psychrotrophic Clostridium botulinum Group II strains, only one type B toxic strain carries one csp gene, whereas none of type E toxic strains has csp genes (Söderholm et al., 2013). The lack of $c s p$ genes in psychrotrophic Group II C. botulinum indicates that the cold tolerance of these strains is due to some other mechanism. In $C$. botulinum ATCC3502 inactivation of just one of the three $\operatorname{csp}$ genes, $\operatorname{csp} B$, resulted in cold sensitive phenotype, suggesting 
that $\operatorname{cspB}$ is the major Csp of Group I C. botulinum (Söderholm et al., 2011). This is also supported by the fact that all C. botulinum Group I and III strains have homologues for $\operatorname{csp} B$ (Söderholm et al., 2013).

\section{COLD SHOCK PROTEINS OF ENTEROPATHOGENIC Yersinia}

The published genome sequences of enteropathogenic Yersinia reveal that they carry several putative Csp encoding genes. $Y$. enterocolitica and $Y$. pseudotuberculosis strains have 6-10, and 7-9 csp genes, respectively. The Csps of Yersinia are highly homologous, and the cold-shock proteins encoding genes of, e.g., Y. pseudotuberculosis IP32953 share 32.8-100\% amino acid and $44.6-99.5 \%$ nucleotide sequence similarity (Table 2). When the csp genes of E. coli K-12 W3110 are compared to the most closely similar csp genes of $Y$. enterocolitica 8081 and $Y$.pseudotuberculosis IP32953, the amino acid sequence similarity varies between 48.6 and $98.6 \%$ (Table 1). Since some of the Csp encoding genes of enteropathogenic Yersinia share a very high amino acid sequence similarity (74.3-98.6\%) with $\operatorname{csp} A$, $\operatorname{csp} B, \operatorname{csp} C, \operatorname{csp} D, \operatorname{csp} E, \operatorname{csp} G$, and $\operatorname{cspI}$ of $E$. coli it can be assumed that they also have common functions. Lower amino acid sequence similarity is observed with $E$. coli genes $\operatorname{csp} F$ and $c s p H$ which function in E. coli is unknown (Czapski and Trun, 2014).

Yersinia enterocolitica, Y. pseudotuberculosis, Yersinia pestis, and Yersinia ruckeri carry a locus containing a tandem $\operatorname{csp} A$ duplication ( $\operatorname{csp} A 1$ and $\operatorname{csp} A 2)$ which produces both monocistronic (CspA1) and bicistronic (CspA1/A2) mRNA templates (Neuhaus et al., 1999). At high temperatures monocistronic mRNA predominates. When the temperature decreases, more bicistronic mRNA is produced but the longer the cold shock lasts, the more monocistronic mRNA is produced (Neuhaus et al., 1999). Compared to E. coli, these monoand bicistronic mRNA templates give $Y$. enterocolitica a better transcriptional capacity during the cold shock. Synthesis of proteins is more efficient when the transcript contains two copies of the protein (Neuhaus et al., 1999).
Annamalai and Venkitanarayanan (2005) studied the Csp expression of Y. enterocolitica in Luria-Bertani (LB) broth, milk, and on pork meat after temperature drop from $30^{\circ} \mathrm{C}$ to $4^{\circ} \mathrm{C}$. CspA1 and CspA2 were first detected $2 \mathrm{~h}$ after cold shock from LB and milk cultures, but it took as long as $8 \mathrm{~h}$ after cold shock to observe detectable levels of Csps on pork meat. On pork meat the delayed expression of Csps and genes might be due to the extended lag phase of $Y$. enterocolitica on solid meat surface compared to liquid medium. Both in LB broth and on pork meat the expression of Csps and genes continued until $24 \mathrm{~h}$ of cold shock suggesting that in Y. enterocolitica Csps are not only needed during the immediate cold shock response but also during the cold acclimation. At $30^{\circ} \mathrm{C}, \mathrm{CspA} 1$ and CspA2 were not observed at all (Annamalai and Venkitanarayanan, 2005).

After cold adaptation, Csp mRNAs must be degraded to liberate ribosomes for translation of mRNAs of non-Csps and thereby to enable growth to resume at low temperature (Neuhaus et al., 2000). Neuhaus et al. (2000) observed correlation between beginning of exponential growth of $Y$. enterocolitica cells and degradation of $\operatorname{csp} A 1 / A 2$ mRNA. After adaptation to cold, $Y$. enterocolitica $\operatorname{csp} A 1 / A 2$ transcripts were smaller than the original transcript, and all cut off at the same sequence (AGUAAA) that was later named the cold shock cut box (CSCbox) (Neuhaus et al., 2003). Mutation of the CSC-box caused a delayed growth resume after cold shock. The CSC-box facilitates the degradation of Csp mRNA. Endonuclease RNaseE first cuts the $\operatorname{csp} A 1 / A 2$ transcript to smaller pieces which are further degraded by PNPase (Neuhaus et al., 2003). PNPase is necessary for $Y$. enterocolitica growth at low temperature (Goverde et al., 1998) and it regulates gene expression by selectively degrading Csp mRNAs (Yamanaka and Inouye, 2001b).

\section{ROLE OF COLD SHOCK PROTEINS DURING NORMAL GROWTH AND IN STRESS RESPONSES UNRELATED TO COLD}

Cold shock proteins are not only produced during cold stress. A minimum of one csp gene is essential for viability of B. subtilis,

TABLE 2 | Nucleotide and amino acid sequence similarity (in percentage) ${ }^{\mathrm{a}}$ of the putative cold shock proteins of Yersinia pseudotuberculosis strain IP32953.

\begin{tabular}{|c|c|c|c|c|c|c|c|c|c|}
\hline Gene name $^{b}$ & yptb1088 & yptb1392 & yptb1423 & yptb1624 & yptb2414 & yptb2950 & yptb3585 & yptb3586 & yptb3587 \\
\hline yptb1088 (210 bp) & - & 46.27 & 53.62 & 84.06 & 79.71 & 66.67 & 73.91 & 73.91 & 72.46 \\
\hline yptb1392 (264bp) & 57.84 & - & 32.84 & 46.27 & 47.76 & 49.25 & 46.27 & 46.27 & 47.76 \\
\hline yptb1423 (210 bp) & 60.00 & 44.61 & - & 49.28 & 49.28 & 47.83 & 49.28 & 49.28 & 47.83 \\
\hline yptb1624 (210 bp) & 75.24 & 53.92 & 58.10 & - & 82.61 & 75.36 & 73.91 & 73.91 & 72.46 \\
\hline yptb2414 (213 bp) & 71.43 & 52.94 & 57.62 & 84.76 & - & 74.29 & 78.57 & 78.57 & 77.14 \\
\hline yptb2950 (213 bp) & 64.76 & 56.37 & 51.90 & 72.86 & 70.42 & - & 92.86 & 92.86 & 88.57 \\
\hline yptb3585 (213bp) & 66.67 & 56.37 & 54.76 & 73.33 & 80.75 & 84.04 & - & 100.00 & 95.71 \\
\hline yptb3586 (213 bp) & 67.14 & 56.37 & 55.24 & 72.86 & 80.28 & 83.57 & 99.53 & - & 95.71 \\
\hline yptb3587 (213 bp) & 66.67 & 57.35 & 53.81 & 72.86 & 79.34 & 83.10 & 95.77 & 96.24 & - \\
\hline
\end{tabular}

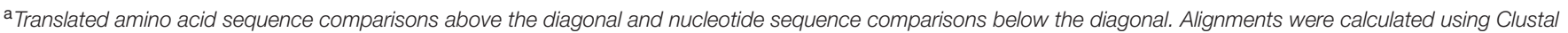

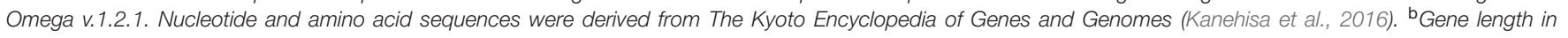
parentheses. 
suggesting that Csps are needed during non-shock growth (Graumann et al., 1997). In E. coli CspA forms 1\% of all soluble proteins at the early exponential growth phase at $37^{\circ} \mathrm{C}$, suggesting that CspA has functions also at optimal growth temperature (Brandi et al., 1999). In E. coli, both growth medium and growth phase have been shown to affect the transcription of csp genes (Czapski and Trun, 2014). In MOPS defined minimal glucose medium $\operatorname{csp} E$ mRNA levels were higher than mRNA levels of other $c s p$ genes, whereas in MOPS defined rich glucose medium transcripts for $\operatorname{csp} A, \operatorname{csp} B$, and $\operatorname{csp} E$ predominated (Czapski and Trun, 2014). In E. coli transcripts of $\operatorname{csp} A$ predominate during the lag phase and first stages of logarithmic growth whereas only small levels of $\operatorname{csp} A$ mRNA can be detected at other stages of growth (Brandi and Pon, 2012). Also nutritional upshift has been shown to induce CspA in E. coli, although the related level of induction was only one-sixth of that caused by cold shock (Yamanaka and Inouye, 2001a).

Functions of non-cold-inducible Csps are yet poorly understood (Tanaka et al., 2012). DNA microarray analysis revealed that deletion of ttcsp1, which is the only non-cold inducible csp gene of $T$. thermophilus, did not alter the gene expression profile compared to wild type at optimal growth conditions. Nevertheless, expression levels of some proteins were significantly upregulated or downregulated in $\Delta t$ tcsp 1 , suggesting that ttCsp1 contributes to translational control (Tanaka et al., 2012). Tanaka et al. (2012) also suggested that different stress factors might alter the nucleotide binding affinities of some Csps. On the contrary, the whole transcriptome of a $\operatorname{csp} A$ mutant of Brucella melitensis revealed that a total of 446 genes were differentially expressed compared to wild type. Differences in expression were especially observed in genes associated with virulence and metabolism and the $\operatorname{csp} A$ mutant also showed reduced growth in minimal medium. Results suggest that $\operatorname{csp} A$ of $B$. melitensis plays a role in virulence and metabolism regulation, but the CspA-mediated regulatory mechanisms are not understood (Wang et al., 2016). These contrary results observed in gene expression of different csp mutants warrant that further research is needed to understand by which mechanism Csps function during normal growth and in stress responses unrelated to cold.

In E. coli, $\operatorname{cspD}$ inhibits DNA replication and is induced during stationary phase to resign growth. Overproduction of this Csp is thus toxic to the cells (Yamanaka et al., 2001; Uppal et al., 2014). CspD has also been linked to biofilms and persister cell formation (Kim and Wood, 2010; Kim et al., 2010). Recently it was also shown that Csps might have a role in buffering deleterious mutations since overexpression of CspA improved fitness of E. coli strains that had accumulated deleterious mutations during long-term laboratory experiments (Rudan et al., 2015). Rudan et al. (2015) suggested that CspA and other RNA chaperones could aid misfolded RNA to adopt functional conformation and thus suppress harmful mutations that affect RNA structure. Since mutation rate can be elevated in response to stress (Hersh et al., 2004; Foster, 2007), it would of interest to investigate whether Csps could also counteract harmful stress-induced mutations.

Derman et al. (2015) revealed that $\operatorname{csp} B$ and $\operatorname{csp} C$, but not $\operatorname{csp} A$, play an important role in $\mathrm{NaCl}, \mathrm{pH}$ and ethanol stress in C. botulinum ATCC3502. Mutation of $\operatorname{csp} A$ and $\operatorname{csp} C$ also reduced motility and hampered flagella formation. In L. monocytogenes CspA is the major cold-shock-responsive Csp, whereas CspB and CspD are involved in host cell invasion (Schmid et al., 2009; Loepfe et al., 2010). Deletion of one or both of $\operatorname{cspB}$ and $c s p D$ resulted in severely impaired Caco- 2 cell invasion, whereas deletion of $\operatorname{csp} A$ had no effect on cell invasion. Simultaneous deletion of $\operatorname{csp} B$ and $\operatorname{csp} D$ or deletion of all three $\operatorname{csp}$ genes of L. monocytogenes resulted in most severe impairment of host cell invasion and also caused reduced intracellular growth in macrophages (Loepfe et al., 2010). Schärer et al. (2013) suggested that Csps contribute to regulation of listeriolysin $\mathrm{O}$, which is a pore-forming cytolysin needed in intracellular survival. In addition, $\operatorname{csp} A$ contributed to oxidative stress tolerance (Loepfe et al., 2010), and single deletion of $\operatorname{csp} D$, but not of $\operatorname{csp} A$ and $\operatorname{csp} B$, resulted in impaired osmotic stress adaptation in L. monocytogenes (Schmid et al., 2009). Since Csps promote L. monocotygenes adaptation against different stress conditions, exposure to one type of stress, e.g., during food production might induce cross-protection against others (Schmid et al., 2009).

\section{CONCLUSION}

Production of Csps is one of the most prominent responses of bacteria to cold shock and recent studies have shown that Csps have a much wider role in stress response of bacteria than previously assumed. Enteropathogenic Yersinia encode several Csps which show a high homology to those of E. coli. Some of these E. coli csp genes are linked to stresses other than cold. Y. enterocolitica CspA1 and CspA2 are known to be involved in cold shock response, however, it is not known what the role of other csp genes is in stress response of enteropathogenic Yersinia. Therefore, knowledge about the function of Csps is needed to be able to develop measures that limit the growth and survival of enteropathogenic Yersinia in various foods during food production and storage.

\section{AUTHOR CONTRIBUTIONS}

RK-T, NH, EP, ML, and HK designed the minireview, RK-T and AH performed sequence comparisons, RK-T and NH drafted the manuscript, EP, ML, and HK critically revised the manuscript.

\section{FUNDING}

This project was supported by the Finnish Veterinary Foundation and the Walter Ehrström Foundation. 


\section{REFERENCES}

Annamalai, T., and Venkitanarayanan, K. (2005). Expression of major cold shock proteins and genes by Yersinia enterocolitica in synthetic medium and foods. J. Food Prot. 68, 2454-2458.

Bae, W., Phadtare, S., Severinov, K., and Inouye, M. (1999). Characterization of Escherichia coli $\operatorname{csp} E$, whose product negatively regulates transcription of $\operatorname{csp} A$, the gene for the major cold shock protein. Mol. Microbiol. 31, 1429-1441. doi: 10.1046/j.1365-2958.1999.01284.x

Bae, W., Xia, B., and Inouye, M. (2000). Escherichia coli CspA-family RNA chaperones are transcription antiterminators. Proc. Natl. Acad. Sci. U.S.A. 97, 7784-7789. doi: 10.1073/pnas.97.14.7784

Brandi, A., and Pon, C. L. (2012). Expression of Escherichia coli cspA during early exponential growth at $37^{\circ} \mathrm{C}$. Gene $492,382-388$. doi: 10.1016/j.gene.2011.10.047

Brandi, A., Spurio, R., Gualerzi, C. O., and Pon, C. L. (1999). Massive presence of the Escherichia coli 'major cold-shock protein' CspA under non-stress conditions. EMBO J. 18, 1653-1659.

Chaikam, V., and Karlson, D. T. (2010). Comparison of structure, function and regulation of plant cold shock domain proteins to bacterial and animal cold shock domain proteins. BMB Rep. 43, 1-8. doi: 10.5483/BMBRep.2010.43.1.001

Charollais, J., Dreyfus, M., and Iost, I. (2004). CsdA, a cold-shock RNA helicase from Escherichia coli, is involved in the biogenesis of 50 S ribosomal subunit. Nucleic Acids Res. 32, 2751-2759. doi: 10.1093/nar/gkh603

Cohen-Or, I., Shenhar, Y., Biran, D., and Ron, E. Z. (2010). CspC regulates rpoS transcript levels and complements hfq deletions. Res. Microbiol. 161, 694-700. doi: 10.1016/j.resmic.2010.06.009

Czapski, T. R., and Trun, N. (2014). Expression of csp gene in E. coli K-12 in defined rich and defined minimal media during normal growth, and after cold-shock. Gene 547, 91-97. doi: 10.1016/j.gene.2014.06.033

Derman, Y., Söderholm, H., Lindström, M., and Korkeala, H. (2015). Role of csp genes in $\mathrm{NaCl}, \mathrm{pH}$, and ethanol stress response and motility in Clostridium botulinum ATCC3502. Food Microbiol. 46, 463-470. doi: 10.1016/j.fm.2014.09.004

Duval, B. D., Mathew, A., Satola, S. W., and Shafer, W. M. (2010). Altered growth, pigmentation, and antimicrobial susceptibility properties of Staphylococcus aureus due to loss of the major cold shock gene cspB. Antimicrob. Agents Chemother. 54, 2283-2290. doi: 10.1128/AAC.01786-09

EFSA and ECDC (2015) European food safety authority, European centre for disease prevention and control. Scientific report of EFSA and ECDC. The European Union summary report on trends and sources of zoonoses, zoonotic agents and food-borne outbreaks in 2013. EFSA J. 13:3991.

Ermolenko, D. N., and Makhatadze, G. I. (2002). Bacterial cold-shock proteins. Cell. Mol. Life Sci. 59, 1902-1913. doi: 10.1007/PL00012513

Etchegaray, J. P., Jones, P. G., and Inouye, M. (1996). Differential thermoregulation of two highly homologous cold-shock genes, cspA and cspB, of Escherichia coli. Genes Cells 1, 171-178. doi: 10.1046/j.1365-2443.1996.d01-231.x

Foster, P. L. (2007). Stress-induced mutagenesis in bacteria. Crit. Rev. Biochem. Mol. Biol. 42, 373-397. doi: 10.1080/10409230701648494

Fredriksson-Ahomaa, M., Lindström, M., and Korkeala, H. (2010) "Yersinia enterocolitica and Yersinia pseudotuberculosis," in Pathogens and Toxins in Foods: Challenges and Interventions, eds V. K. Juneva and J. N. Sofos (Washington, DC: ASM Press), 164-180.

Fredriksson-Ahomaa, M., Stolle, A., and Korkeala, H. (2006). Molecular epidemiology of Yersinia enterocolitica infections. FEMS Immunol. Med. Microbiol. 47, 315-329. doi: 10.1111/j.1574-695X.2006.00095.x

Fukushima, H., Gomyoda, M., Shiozawa, K., Kaneko, S., and Tsubokura, M. (1988). Yersinia pseudotuberculosis infection contracted through water contaminated by a wild animal. J. Clin. Microbiol. 26, 584-585.

Giuliodori, A. M., Di Pietro, F., Marzi, S., Masquida, B., Wagner, R., Romby, P., et al. (2010). The cspA mRNA is a thermosensor that modulates translation of the cold-shock protein CspA. Mol. Cell 37, 21-33. doi: 10.1016/j.molcel.2009.11.033

Goldstein, J., Pollitt, N. S., and Inouye, M. (1990). Major cold shock protein of Escherichia coli. Proc. Natl. Acad. Sci. U.S.A. 87, 283-287.

Goverde, R. L. J., Huis in't Veld, J. H. J., Kusters, J. G., and Mooi, F. R. (1998). The psychrotropic bacterium Yersinia enterocolitica requires expression of pnp, the gene for polynucleotide phosphorylase, for growth at low temperature $\left(5^{\circ} \mathrm{C}\right)$. Mol. Microbiol. 28, 555-569.

Graumann, P., Wendrich, T. M., Weber, M. H. W., Schröder, K., and Marahiel, M. A. (1997). A family of cold shock proteins in Bacillus subtilis is essential for cellular growth and for efficient protein synthesis at optimal and low temperatures. Mol. Microbiol. 25, 741-756. doi: 10.1046/j.13652958.1997.5121878.x

Graumann, P. L., and Marahiel, M. A. (1996). Some like it cold: response of microorganisms to cold shock. Arch. Microbiol. 166, 293-300. doi: $10.1007 / \mathrm{s} 002030050386$

Hébraud, M., and Potier, P. (1999). Cold shock response and low temperature adaptation in psychrotrophic bacteria. J. Mol. Microbiol. Biotechnol. 1, 211-219.

Hersh, M. N., Ponder, R. G., Hastings, P. J., and Rosenberg, S. M. (2004). Adaptive mutation and amplification in Escherichia coli: two pathways of genome adaptation under stress. Res. Microbiol. 155, 352-359. doi: 10.1016/j.resmic.2004.01.020

Ivancic, T., Jamnik, P., and Stopar, D. (2013). Cold shock CspA and CspB protein production during periodic temperature cycling in Escherichia coli. BMC Res. 6:248. doi: 10.1186/1756-0500-6-248

Jalava, K., Hakkinen, M., Valkonen, M., Nakari, U. M., Palo, T., Hallanvuo, S., et al. (2006). An outbreak of gastrointestinal illness and erythema nodosum from grated carrots contaminated with Yersinia pseudotuberculosis. J. Infect. Dis. 194, 1209-1216. doi: 10.1086/508191

Jiang, W., Hou, Y., and Inouye, M. (1997). CspA, the major cold-shock protein of Escherichia coli, is an RNA chaperone. J. Biol. Chem. 272, 196-202. doi: $10.1074 /$ jbc.272.1.196

Jin, B., Jeong, K. W., and Kim, Y. (2014). Structure and flexibility of the thermophilic cold-shock protein of Thermus aquaticus. Biochem. Biophys. Res. Commun. 451, 402-407. doi: 10.1016/j.bbrc.2014.07.127

Jones, P. G., VanBogelen, R. A., and Neidhardt, F. C. (1987). Induction of proteins in response to low temperature in Escherichia coli. J. Bacteriol. 169, 2092-2095.

Jung, Y. H., Yi, J. Y., Jung, H. J., Lee, Y. K., Lee, H. K., Naicker, M. C., et al. (2010). Overexpression of cold shock protein A of Psychromonas arctica KOPRI 22215 confers cold-resistance. Protein J. 2010, 136-142. doi: 10.1007/s10930010-9233-9

Kanehisa, M., Sato, Y., Kawashima, M., Furumichi, M., and Tanabe, M. (2016). KEGG as a reference resource for gene and protein annotation. Nucleic Acids Res. 44, D457-D462. doi: 10.1093/nar/gkv1070

Kim, Y., Wang, X., Zhang, X. S., Grigoriu, S., Page, R., Peti, W., et al. (2010). Escherichia coli toxin/antitoxin pair MqsR/MqsA regulate toxin CspD. Environ. Microbiol. 12, 1105-1121. doi: 10.1111/j.1462-2920.2009.02147.x

Kim, Y., and Wood, T. K. (2010). Toxins Hha and CspD and small RNA regulator $\mathrm{Hfq}$ are involved in persister cell formation through MqsR in Escherichia coli. Biochem. Biophys. Res. Commun. 391, 209-213. doi: 10.1016/j.bbrc.2009. 11.033

Lee, J., Jeong, K. W., Jin, B., Ryu, K. S., Kim, E. H., Ahn, J. H., et al. (2013). Structural and dynamic features of cold-shock proteins of Listeria monocytogenes, a psychrophilic bacterium. Biochemistry 52, 2492-2504. doi: 10.1021/bi301641b

Loepfe, C., Raimann, E., Stephan, R., and Tasara, T. (2010). Reduced host cell invasiveness and oxidative stress tolerance in double and triple csp gene family deletion mutants of Listeria monocytogenes. Foodborne Pathog. Dis. 7, 775-783. doi: $10.1089 /$ fpd.2009.0458

Mega, R., Manzoku, M., Shinkai, A., Nakagawa, N., Kuramitsu, S., and Masui, R. (2010). Very rapid induction of a cold shock protein by temperature downshift in Thermus thermophilus. Biochem. Biophys. Res. Commun. 399, 336-340. doi: 10.1016/j.bbrc.2010.07.065

Michaux, C., Martini, C., Shioya, K., Ahmed Lecheheb, S., Budin-Verneuil, A., Cosette, P., et al. (2012). CspR, a cold shock RNA-binding protein involved in the long-term survival and the virulence of Enterococcus faecalis. J. Bacteriol. 194, 6900-6908. doi: 10.1128/JB.01673-12

Mitta, M., Fang, L., and Inouye, M. (1997). Deletion analysis of cspA of Escherichia coli: requirement of the AT-rich UP element for cspA transcription and the downstream box in the coding region for its cold shock induction. Mol. Microbiol. 26, 321-335. doi: 10.1046/j.1365-2958.1997.5771943.x

Nakashima, K., Kanamaru, K., Mizuno, T., and Horikoshi, K. (1996). A novel member of the cspA family of genes that is induced by cold shock in Escherichia coli. J. Bacteriol. 178, 2994-2997. 
Neuhaus, K., Anastasov, N., Kaberdin, V., Francis, K. P., Miller, V. L., and Scherer, S. (2003). The AGUAAA motif in cspA1/A2 mRNA is important for adaptation of Yersinia enterocolitica to grow at low temperature. Mol. Microbiol. 50, 1629-1645. doi: 10.1046/j.1365-2958.2003.03795.x

Neuhaus, K., Francis, K. P., Rapposch, S., Görg, A., and Scherer, S. (1999). Pathogenic Yersinia species carry a novel, cold-inducible major cold shock protein tandem gene duplication producing both bicistronic and monocistronic mRNA. J. Bacteriol. 181, 6449-6455.

Neuhaus, K., Rapposch, S., Francis, K. P., and Scherer, S. (2000). Restart of exponential growth of coldshocked Yersinia enterocolitica occurs after down-regulation of cspA1/A2 mRNA. J. Bacteriol. 182, 3285-3288. doi: 10.1128/JB.182.11.3285-3288.2000

Nuorti, J. P., Niskanen, T., Hallanvuo, S., Mikkola, J., Kela, E., Hatakka, M., et al. (2004). A widespread outbreak of Yersinia pseudotuberculosis O:3 infection from iceberg lettuce. J. Infect. Dis. 189, 766-774. doi: 10.1086/381766

Pärn, T., Hallanvuo, S., Salmenlinna, S., Pihlajasaari, A., Heikkinen, S., TelkkiNykänen, H., et al. (2015). Outbreak of Yersinia pseudotuberculosis O:1 infection associated with raw milk consumption, Finland, spring 2014. Euro. Surveill. 20, 13-19. doi: 10.2807/1560-7917.ES.2015.20.40.30033

Phadtare, S. (2004). Recent developments in bacterial cold-shock response. Curr. Issues Mol. Biol. 6, 125-136.

Phadtare, S. (2012). Escherichia coli cold-shock gene profiles in response to over-expression/deletion of CsdA, RNase R and PNPase and relevance to lowtemperature RNA metabolism. Genes Cells 17, 850-874. doi: 10.1111/gtc.12002

Phadtare, S., and Inouye, M. (2001). Role of CspC and CspE in regulation of expression of RpoS and UspA, the stress response proteins in Escherichia coli. J. Bacteriol. 183, 1205-1214. doi: 10.1128/JB.183.4.1205-1214.2001

Phadtare, S., Inouye, M., and Severinov, K. (2002). The nucleic acid melting activity of Escherichia coli CspE is critical for transcription antitermination and cold acclimation of cells. J. Biol. Chem. 277, 7239-7245. doi: 10.1074/jbc.M111496200

Phadtare, S., and Severinov, K. (2005). Extended -10 motif is critical for activity of the cspA promoter but does not contribute to low-temperature transcription. J. Bacteriol. 187, 6584-6589. doi: 10.1128/JB.187.18.6584-6589.2005

Phadtare, S., and Severinov, K. (2010). RNA remodeling and gene regulation by cold shock proteins. RNA Biol. 7, 788-795. doi: 10.4161/rna.7.6.13482

Rath, D., and Jawali, N. (2006). Loss of expression of cspC, a cold shock family gene, confers a gain of fitness in Escherichia coli K-12 strains. J. Bacteriol. 188, 6780-6785. doi: 10.1128/JB.00471-06

Rudan, M., Schneider, D., Warnecke, T., and Krisko, A. (2015). RNA chaperones buffer deleterious mutations in E. coli. Elife 25, 4. doi: 10.7554/eLife.04745

Schärer, K., Stephan, R., and Tasara, T. (2013). Cold shock proteins contribute to the regulation of listeriolysin $\mathrm{O}$ production in Listeria monocytogenes. Foodborne Pathog. Dis. 10, 1023-1029. doi: 10.1089/fpd.2013.1562

Schmid, B., Klumpp, J., Raimann, E., Loessner, M. J., Stephan, R., and Tasara, T. (2009). Role of cold shock proteins in growth of Listeria monocytogenes under cold and osmotic stress conditions. Appl. Environ. Microbiol. 75, 1621-1627. doi: 10.1128/AEM.02154-08

Shenhar, Y., Biran, D., and Ron, E. Z. (2012). Resistance to environmental stress requires the RNA chaperones $\mathrm{CspC}$ and CspE. Environ. Microbiol. Rep. 4, 532-539. doi: 10.1111/j.1758-2229.2012.00358.x

Söderholm, H., Jaakkola, K., Somervuo, P., Laine, P., Auvinen, P., Paulin, L., et al. (2013). Comparison of Clostridium botulinum genomes shows the absence of cold shock protein coding genes in type E neurotoxin producing strains. Botulinum J. 2, 189-207. doi: 10.1504/TBJ.2013.055662

Söderholm, H., Lindström, M., Somervuo, P., Heap, J., Minton, N., Lindén, J., et al. (2011). cspB encodes a major cold shock protein in
Clostridium botulinum ATCC 3502. Int. J. Food Microbiol. 146, 23-30. doi: 10.1016/j.ijfoodmicro.2011.01.033

Tanaka, T., Mega, R., Kim, K., Shinkai, A., Masui, R., Kuramitsu, S., et al. (2012). A noncold-inducible cold shock protein homolog mainly contributes to translational control under optimal growth conditions. FEBS J. 279, 1014-1029. doi: 10.1111/j.1742-4658.2012.08492.x

Uppal, S., Akkipeddi, V. S., and Jawali, N. (2008). Posttranscriptional regulation of cspE in Escherichia coli: involvement of the short 5'-untranslated region. FEMS Microbiol. Lett. 279, 83-91. doi: 10.1111/j.1574-6968.2007. 01009.x

Uppal, S., Shetty, D. M., and Jawali, N. (2014). Cyclic AMP receptor protein regulates cspD, a bacterial toxin gene, in Escherichia coli. J. Bacteriol. 196, 1569-1577. doi: 10.1128/JB.01476-13

Wang, N., Yamanaka, K., and Inouye, M. (1999). CspI, the ninth member of the CspA family of Escherichia coli, is induced upon cold shock. J. Bacteriol. 181, 1603-1609.

Wang, Z., Liu, W., Su, T., Bie, P., and Wu, Q. (2016). RNA-seq reveals the critical role of CspA in regulating Brucella melitensis metabolism and virulence. Sci. China Life Sci. 59, 417-424. doi: 10.1007/s11427-015-4981-6

Wang, Z., Wang, S., and Wu, Q. (2014). Cold shock protein A plays an important role in the stress adaptation and virulence of Brucella melitensis. FEMS Microbiol. Lett. 354, 27-36. doi: 10.1111/1574-6968.12430

Xia, B., Ke, H., and Inouye, M. (2001). Acquirement of cold sensitivity by quadruple deletion of the cspA family and its suppression by PNPase S1 domain in Escherichia coli. Mol. Microbiol. 40, 179-188. doi: 10.1046/j.13652958.2001.02372.x

Yamanaka, K. (1999). Cold shock response in Escherichia coli. J. Mol. Microbiol. Biotechnol. 1, 193-202.

Yamanaka, K., Fang, L., and Inouye, M. (1998). The CspA family in Escherichia coli: multiple gene duplication for stress adaptation. Mol. Microbiol. 27, 247-255. doi: 10.1046/j.1365-2958.1998.00683.x

Yamanaka, K., and Inouye, M. (1997). Growth-phase-dependent expression of $\operatorname{cspD}$, encoding a member of the CspA family in Escherichia coli. J. Bacteriol. 179, 5126-5130.

Yamanaka, K., and Inouye, M. (2001a). Induction of CspA, an E. coli major coldshock protein, upon nutritional upshift at 37 degrees C. Genes Cells 6, 279-290. doi: 10.1046/j.1365-2443.2001.00424.x

Yamanaka, K., and Inouye, M. (2001b). Selective mRNA degradation by polynucleotide phosphorylase in cold shock adaptation in Escherichia coli. J. Bacteriol. 183, 2808-2816. doi: 10.1128/JB.183.9.2808-281 6.2001

Yamanaka, K., Zheng, W., Crooke, E., Wang, Y. H., and Inouye, M. (2001). CspD, a novel DNA replication inhibitor induced during the stationary phase in Escherichia coli. Mol. Microbiol. 39, 1572-1584. doi: 10.1046/j.13652958.2001.02345.x

Conflict of Interest Statement: The authors declare that the research was conducted in the absence of any commercial or financial relationships that could be construed as a potential conflict of interest.

Copyright (c) 2016 Keto-Timonen, Hietala, Palonen, Hakakorpi, Lindström and Korkeala. This is an open-access article distributed under the terms of the Creative Commons Attribution License (CC BY). The use, distribution or reproduction in other forums is permitted, provided the original author(s) or licensor are credited and that the original publication in this journal is cited, in accordance with accepted academic practice. No use, distribution or reproduction is permitted which does not comply with these terms. 